\title{
The politics of making and unmaking (sustainable) futures: introduction to the special feature
}

\author{
Henrike Knappe ${ }^{1} \cdot$ Anne-Katrin Holfelder $^{1}\left[\right.$ - David Löw Beer ${ }^{1} \cdot$ Patrizia Nanz $^{1}$
}

Received: 23 April 2019 / Accepted: 7 May 2019 / Published online: 19 May 2019

(c) The Author(s) 2019

\section{Introduction}

From the onset of what we now call sustainability politics, "the future" has been an important frame of reference for political intent and action, as well as for (re)aligning one's moral compass. The idea of sustainable development clearly emerged from the recognition that the planet's resources and capacities are limited. The paradigm of development has had to be rethought in a more future-sensitive, future-oriented way, taking into account inter alia our perceived moral obligation toward future generations. In 1987, Our Common Future, also known as "The Brundtland Report", famously expressed this new outlook thus: "development that meets the needs of the present without compromising the ability of future generations to meet their own needs" (WCED 1987, p 37). Since that time, the politics and policies of development and progress embedded in environmental concerns and limits to growth are torn between the future-making practices of enabling and transforming, on the one hand, and those of preservation and conservation on the other. Future-making practices are social and political endeavours that implicitly or explicitly establish relationships or refer to future situations. This broad definition takes into account practices as diverse as policy planning, scientific

Handled by Osamu Saito, United Nations University Institute for the Advanced Study of Sustainability, Japan.

We thank the participants of the IASS-workshop on "Futurisation of Politics" for the inspiring discussions and helpful comments. Furthermore, we thank Barbara Muraca, Barbara Adam and Graham Smith for their valuable comments on earlier versions of this article.

Anne-Katrin Holfelder

Anne-Katrin.Holfelder@iass-potsdam.de

1 Institute for Advanced Sustainability Studies e.V., Potsdam, Germany anticipation, biographical choices or the behaviour of different social groups. Examples of future-making practices that enable and transform can be found in cities' or civil society groups' sustainability initiatives such as the transition towns or urban gardening projects, as well as in geoengineering practices and technological innovation in general.

Examples of future-making practices that preserve and sustain can be found in nature conservation politics and movements, risk politics, as well as in areas of legal regulation-consider, for instance, the precautionary principle or the debate over human rights for future generations. Both modes of future making (transformative and preservative) are legitimated through different sustainable future narratives. They are not "naturally occurring", a priori or "given" by some external, higher authority; rather, they emerge from different social and political contexts and underlying sociopolitical norms and goals. These modes of future making arise, change or shift with our concrete endeavours to deal with the future in various political arenas such as UN negotiations, social movement activities or parliamentary debates; in social spaces such as schools, sports clubs or book shops; and in accordance with economic structures, market logic, investments or growth. Effective future-making practices can become powerful tools for creating (new) orders, empowering or excluding actors, and even for preserving or transforming fundamental values such as those that determine what people perceive as the "good life" or a desirable future. Power inequalities and power struggles are thus part of any future-making practice, and making these asymmetries explicit is one major task as regards the political dimension of future making in sustainability politics. This means that a first step would be to ask who is involved in making futures, why are specific measures taken, and what kind of futures result (Vervoort and Gupta 2018). To raise these questions and examine them is one of the main goals of this special feature. 
In approaching these questions, we observe with some vexation that making futures more sustainable is often seen as a matter of technological, scientific or economic endeavour but not as something of political concern: futures have become depoliticized. Our second main aim, therefore, will be to (re)conceive and discuss possible ways to overcome power asymmetries, inequalities and exclusions in future making. We view the political as normative and we argue that, in sustainability politics, to do justice to present and future generations, it is not enough to approach issues concerning the future only from a technocratic or managerial perspective. It is necessary that contemporary future practices be opened up to public scrutiny and contestation; this is what we refer to as politicization (Zürn et al. 2012). "Reintroduc[ing] the political" (Lövbrand et al. 2015, p 216) has become an urgent matter for debates about the future of the planet and its inhabitants, and for developing corresponding, appropriate future practices. Politicization entails a broadening of practices towards more pluralistic and imaginative understandings of the future, and putting measures in place to ensure equal access to processes for developing such practices. Politicization is based on an understanding of sustainability in which the contested character of democracy figures as a necessary and productive component.

With this special feature, we hope to shed light on social and political practices that make or unmake sustainable futures. Future-making practices take place in complex temporalities. They evolve from multiple interactions between the production, use and organization of knowledge about the future (Granjou et al. 2017), the structural restrictions imposed on collective and individual actors dealing with the future (Sardar 1999), the impulses and necessities of change, the visions of the future and the ideas that determine our perception of it (Leccardi 2012; Milkoreit 2016; Appadurai 2013), and the ethical principles determining what constitutes a just and "good" future (Adam and Groves 2007). Building on different debates in the fields of education, environmental humanities, history, political economy, political science, science and technology studies and sociology, this special feature aims to critically and explicitly analyse the pitfalls and problems of future-making practices and to develop a more nuanced understanding of practices for a sustainable future and the conditions that enable them.

\section{Temporal politics-the future as political}

Historically, the capacity to envision, plan, and make futures has been a powerful resource, and it still is today (Koselleck 2004). Power struggles over perceptions of the future shape how politics is done in and for the present as well as for the future. When the future ceased to be a matter of fate in the hands of gods (Adam 2010) and shifted into the realm of peoples' actions and responsibilities, different modes of future making emerged and competed with each other for acceptance. On a more general level, a well-established distinction of "futures" is that of present futures and future presents (Luhmann 1990; Adam and Groves 2007). Present futures are utopian notions based on images of a dreaded future or a desired one-for example, the ecological crisis (in the case of the former) or the emancipation from the yoke of political oppression (in the case of the latter). In this regard, present futures are phenomenological approaches to the future. The future lies beyond a time horizon that delineates it from the present; it can be approached but never reached (like the horizon that delineates the earth from the sky) (Luhmann 1990, p 132). In contrast, science and technology attempt to measure and anticipate the future presents, the actual presents that come immediately after the present present. According to Luhmann, science and technology try to reduce the complexity of future presents by cutting them into smaller sequences bound by correlations and causalities that reach back into the (present) present; thus, science and technology are supposed to give people in the present choices and the ability to act upon the future (ibid.). Both modes of the future faced severe crises in the twentieth century. Present futures seem to have failed to fulfil the hopes that were connected to them. The grand utopic visions of socialism, communism, capitalism or even democracy did not live up to the hopes that people and societies projected onto them. As a consequence, these utopic visions vanished from the political sphere and are more likely to be found now in societal niches. Future presents and with them the societal, reductive belief that scientific method can secure and guarantee the future (Adam and Groves 2007, p 171) have been shattered with equal ferocity. With the emerging failures of long-term prediction-for example, of the consequences of nuclear energy use-the future has become an ever more precarious and unpredictable matter in modernity (Adam 2010). These crises - the failure of visionary potential and predictability of the future, respectively-in modern Western societies have led to changing ideas for approaching the future as a social phenomenon. Nowotny (1994), for example, states that the future is captured by and vanishes in an ever expanding present. The sequencing of time periods into smaller units and their effects on people's experience of time are also contained in Rosa's thesis of an acceleration of almost every part of life, which he sees rooted in the capitalist logic requiring steady growth and profit making (Rosa 2016).

Beyond those grand narratives, we also want to explore the actual practices of future making that occur within those broader structures (e.g. economic and political systems) and discourses, often challenging them. Here, we want to outline the different ways of referring to the future and building futures, grasping their conflictual nature, contradictions 
and specific character traits. This special feature points to blind spots in the political and social dimensions of future making. It seeks to investigate what kind of things block transformation process and what the potentials for these processes are. Roughly adopting the broader distinction between future presents and present futures, we want to distinguish between future-making practices that refer to futures for the present as concrete visions and plans intended to facilitate decisions in the present, and those that refer to presents for the future as images and knowledge that evolve in the present and affect the future in different ways. Futures for the present are built, for example and among other things, by highlighting pathways for developing viable climate policy (Beck and Mahony 2017) or by envisioning utopian technological futures in climate engineering. On the other hand, presents for the future emerge, for example, from practices of political decision-making on renewable energy or how public investments are made. While we can observe futures for the present and presents for the future as concrete practices of future making, both modes are also connected to each other. For example, concrete visions can potentially materialize in transformative actions; in so doing, they can have impacts on the future and thereby become presents for the future. Conversely, the different futures implied by concrete actions and decisions can have an effect on how people envision their own or societal futures and, in so doing, these implied futures thus become relevant for creating futures for the present. These future-making practices can influence whether people see the future as something predetermined, as something isolated from them or as an open space to be filled. Zooming in on current power struggles over future outlooks, we see that "future" in the field of environmental policymaking is often narrowly defined in anticipatory scientific terms, that (young) people disengage with future planning and visioning, and that particularly the "economization" of future practices closes potential spaces of action for future generations. Adam (1998), for example, captures those patterns as "industrial time", which is structured by "(a) the invariable beat of the clock, (b) the economic commodification of time and (c) the scientific use of time as measure for abstract motion." (Adam 1998, p 11). This linear, economic and laboratory conception of time strongly influences contemporary sustainability politics and turns a blind eye to all the other temporalities of environmental degradation or hazards that we face today (ibid.). More recently, sustainability politics also claims "to rethink and redesign the prevailing temporal orders of human-nature relationships" (Bornemann and Strassheim 2019). Governing time in innovative ways is a central feature of sustainability politics, Bornemann and Strassheim argue. Strategies for social change towards sustainability will vary with regard to their emphasis on "various temporal aspects, such as reform, rupture, innovation or short- and long-term adaptation" (Adloff and Neckel 2019). Sustainability politics are thus attempts to make an uncertain future (more) predictable and possibly governable.

Before we turn to some of the normative approaches that we find useful for further exploring the possibilities of politicizing the future, we want to briefly outline the main critical assessments of the politics of current future making in Western societies to explore the who, why and what of future-making practices. These criticisms point primarily to the exclusive circles of future making, the unequal and abbreviated societal futures and the plundering or colonization of the future itself (Adam and Groves 2007).

The rise of scientific prediction and forecasting methods and technologies has had an enormous impact on the state of anticipation in which we currently live (Granjou et al. 2017). Futures are widely viewed through the lens of scientific anticipation. The belief in an anticipated and thus secure (determined) future has spread into many areas of political and social life. Anticipation has transformed many areas of science itself away from exploring real-world phenomena towards speculating about potential phenomena and events (ibid). Exclusively relying on forms of scientific anticipation can have tremendous effects on sustainability politics, as the example of foresight shows. Foresight entails the critical analysis of long-term developments, and the discussion and implementation of future-oriented strategies. Solutionoriented foresight has meant shifting away from merely projecting likely developments to actively shaping futures. For example, in the wake of its Fourth Assessment Report (2007), the International Panel on Climate Change (IPCC) altered its strategy for the construction of Emission Concentration Pathways and implemented the new Representative Concentration Pathways (RCPs). Before RCPs, various scenarios had been constructed, with each making different assumptions about the future development of various physical, ecological, and socioeconomic phenomena. RCPs, in contrast, are based only on anticipated greenhouse gas concentrations or radiative forcing (RF) and do not anticipate particular social or technical developments. Critics allege that the highly ambitious RCP 2.6 presents the $2{ }^{\circ} \mathrm{C}$ target as a technically feasible goal (Beck and Mahony 2017), without clearly elucidating its (RCP 2.6's) hypothetical aspects, namely that this pathway relies on as-yet non-existent negative emission technologies (NETs) and high carbon prices (Van Vuuren et al. 2011). Although it is explicitly intended to create solutions for urgent environmental problems, scientific knowledge about the future might not have the desired political impact; instead, it tends to neutralize "attempts at collective anticipatory action to prevent further degradation of ecological order" (Granjou et al. 2017, p 7).

On a societal level, Leccardi (2012) describes a "crisis of the future" for Western societies. Unlike the BabyBoomer generation, who were united by a positive vision 
of the future, members of the Millennial Generation face an unknown and contingent future which they respond to by either embracing flexibility and change ("future without a project") or engaging in short-term projects wherein the future is perceived as an "extended present" (Nowotny 1994). On both approaches, openness is absent. It is more often the case that young people with limited economic and social resources will view the future as an extended present. As a consequence, "the future is not seen as something one acts on, but rather as something which acts upon oneself" (Holfelder 2019). Planning for the future becomes irrelevant and loses its meaning (Leccardi 2012, p 66). Time is experienced as accelerated and momentary experiences are overlain with a constant feeling of busyness (Rosa 2016). Technological innovations promote "an ideology of the present, an ideology of the future now, which in turn paralyses all thought about the future" (Augé 2014, p 3). The effects of social inequalities and global injustices in the present also shape many people's outlooks on the future. Many societal groups do not have the opportunities to plan their own futures or to emancipate themselves from hegemonic, imposed visions of the future (ibid.). Many people in the Global South do not have the capacity to aspire to futures that are independent from the Western-dominated Global North (Appadurai 2013). All of this indicates an inability to imagine or conceive alternative (emancipated) futures, although being able to do so is an essential precondition for being able to design sustainable futures.

In addition to present inequalities in future practices, the capacity of future generations to act and decide upon political issues is diminished by political actions in the present (Adam and Groves 2007; Caney 2009; Thompson 2010). ${ }^{1}$ Political decisions, for example, favouring nuclear energy or subsidizing energy-intense industries, deeply affect future generations. This has been possible up to now because future generations and their life circumstances have been largely "decontextualized and depersonalized" to "plunder and pollute [into the future] with impunity" (Adam and Groves 2007, p 13)]. Such practices are based on a commodification of the future whereby the future is treated as if it were a good that can be traded against the present and, at the same time, remain unconnected to it. Mainstream economic models assume trade-offs between present and future consumption and production; within such models, future costs and benefits are usually valued less than present ones. This practice of social discounting (Ramsey 1928) thus reduces the incentives for longer term investments aligned to more

\footnotetext{
1 This refers to the big debate on intergenerational justice and sustainability politics, where different criteria for the harm done to future generations are discussed. We do not have the space here to outline the debate in detail.
}

sustainable development pathways. Mainstream economic models also lack the ability to account for historic as well as qualitative change, and they ignore path dependencies. Time is wrongly considered to be reversible in some sense (Hicks 1976, p 135), as if it were possible to always restore something. And it is usually assumed that technology can substitute for nature. This view has major implications for the future: it creates the illusion that a society is on a sustainable trajectory as long as the sum of all capital (i.e. manufactured, financial, social, human, and natural) does not decrease. This implies that people in the present can substitute nature with technology or, as argued earlier, that present generations can devastate the natural environment provided that they bequeath to future generations enough money or goods to offset the damage.

\section{Politicizing future making: relations and openings}

We learn from those critical accounts of future making that not only are the opportunities of future generations diminished, but so too are the agency and possible futures of many people living in the present. This impoverishes the scope and diversity of future visions, and weakens the individual and collective capacity to imagine and act upon alternatives, because "[o]ur imagination is to a large extent bound to the systems we live in" (Milkoreit 2016, p 172). Thus, in the following paragraphs, we argue from the normative perspective that it must be acknowledged that future-making practices are always tied to present economic, political and societal contexts. However, in those contexts is still room to resist and to transform and shape established (future) practices (Butler 2004). Hence, the specific contexts in which people live and the relationships-be they harmful or empowering-that exist between individuals feed into the possible practices of democratic, sustainable, and pluralized futures. Future practices can only be seen as something performed in the contexts and presence of human beings who are bound together by "inhabit[ing] the world" (Arendt 1958, p XII). Acknowledging these de facto, default unchosen relations is the only way to extend equity beyond borders:

[T] he political aim is to extend equality ... to those none of us ever chose (or did not recognize that we chose) and with whom we have an enduring obligation to find a way to live. For whoever "we" are, we are also those who were never chosen, who emerge on this earth without everyone's consent, and who belong, from the start, to a wider population and a sustainable earth (Butler 2015, p 116). 
On a global level, Butler (2015) defines this relational account as cohabitation of the earth. ${ }^{2}$ Although she makes her case with respect to present, global humanity, "humanity" can also be read to include temporally distant future generations, because the theory she proposes is based on the mutual dependence of human lives. In the same way that humans depend on one another in the present, they also depend on the legacy left to them by people in the past (just as future generations will depend on the legacy we leave them). This and other concepts of intergenerational justice rest on ideas of interpersonal relations and responsibilities (Groves 2014; Fritsch 2018). According to Rosa (2016); to live a good and meaningful life, we must establish and maintain relationships of resonance. When individuals are isolated and alienated from past, present and future persons, they tend to perceive their responsibility towards future generations as a loss (detraction from their own well-being) or a burden (Faets and Tamoudi 2017). Therefore, relationships to past and future generations seem crucial for strengthening positive pathways towards the future. Chris Groves goes a step further, suggesting that we look at people in the future as potential co-creators of their own present.

The concept of generativity defines conditions under which these relations from one generation to the next can be established (King 2015, p 29). Being "generative" means caring and providing resources (including time) for a future from which one is excluded. This means that the current generations must recognize their own transience-a feat not easily accomplished because in today's modern societies "limits" are perceived negatively (ibid.). Continuity is also needed for change (King 2013; Leccardi 2012). The societal interpretative patterns that have emerged in the past create continuity and provide linking points between generations. They set the framework conditions in which the individual holds the potential for discontinuity (and thus change) through his/her reinterpretation of the framework. Situating oneself in historical and social time is a necessary first step for initiating change. Because modern societies tend to emphasize ahistorical concepts of progress, they also tend to overlook these interpretive patterns built into their worlds by previous generations. Generativity stresses the importance of tangible relations between past, present and future generations; this is crucial because it overcomes abstract and detached notions of future beings for whom it is difficult—challenging, to say the least—-to feel any affinity for or responsibility towards.

If we acknowledge the relationality that is inherently and necessarily connected to future-making practices, then the

\footnotetext{
2 Arendt claims that human beings cannot choose to deny the heterogeneity of human life on Earth and thus are bound together by this unchosen mutual obligation to grant one another freedom.
}

task becomes to politicize the future, that is, to open up future making to public contestation and wider circles of society and to shift or change the dominant ways we have of dealing with it. Wright (2010) argues that, while major systemic disruption such as revolution is implausible in liberal capitalist societies, the potential for openings still exists. Such openings can lead to minor adaptions within the current system or to major emancipatory shifts. How a "real utopia" (Wright 2010) can be put into practice will depend largely on the inherent future visions. According to Wright, "real utopias" are necessary pragmatic interventions that allow us to "embrace [...] this tension between dreams and practice" (ibid.: 4). Our ability to conceive of ways to resist hegemonic dominance is shaped by our visions of the future; conversely, in the absence of these visions, emancipatory practices cannot emerge (ibid.). Thus, political spaces in which multiple future visions and practices can be made visible and enabled are crucial for any democratic considerations of the future.

Going beyond sociotechnical futures and opening up for more diverse visions is also a methodological matter. For example, acknowledging the co-production and relationality of future visions in energy transition (away from coal and nuclear powered to safer and more environmentally friendly renewable sources) can pave the way to better detecting, reconstructing and understanding the plethora of diverse future visions resulting from public and civil society interventions as Longhurst and Chilvers show in this special feature. Low and Schäfer (2019) show how different predictive and anticipatory methods in climate engineering create futures that are predominantly economic and techni$\mathrm{cal}$; they point to methods that open up diverse scenarios through deliberative stakeholder engagement. Shifting the perspective from a purely managerial approach to time and future, to future making as open and experimental practices also provides us with new insights (David and Gross 2019). Here, we can see the great potential in education (Kaufmann et al. 2019) because educational settings can offer spaces for critical thinking and reflection as well as spaces for experimentation and conceiving or developing alternatives.

\section{The contributions}

This special feature begins with an essay by Lucian Hölscher on the temporal notion of "future pasts" in historical novels, everyday practices and politics (Hölscher 2019). In fictional settings, future archaeologists construct a past (the author's present) and, in so doing, open up a plethora of possible presents and futures. Hölscher claims that viewing the present from one specific, anticipated future standpoint is a common, everyday modern practice, which unburdens the present by freeing it of ambiguities. Future pasts provide us 
with a powerful instrument to interpret and validate present politics (futures for the present).

Two articles in this volume deal with the political, theoretical and ethical connotations of future-making practices. Rosine Kelz raises the question of future orientation in political theories (Kelz 2019). She analyses the work of Arendt, Cavell and Derrida, and interprets them in terms of their potential for open futures. Instead of arguing the necessity of some new political theory which would incorporate long-term perspectives to address current ecological threats (e.g. climate change), she contends that future orientation is already inherent in the theory of democracy.

Christopher Groves juxtaposes the modern concept of the future as an extension of the present self, (futures for the present as Hölscher described it) and the reflexive counterconcept where future is something "wholly other" than the present and burdened with unintended consequences of the present (presents for the future) (Groves 2019). Groves argues that neither is convincing as moral political tenet. In contrast, Groves suggests to conceptualize future through theories of attachments where present and future people are connected in solidarity through the "holding environment" in which they both exist.

Educational approaches to sustainable futures are offered three contributions to this special feature. Sarah Amsler identifies a "blind spot" in analyses of social and ecological justice based on currently dominant ontological principles (Amsler 2019). Today's popular ontology relies on separation or separateness (individualism carried to its logical extreme), rationality and certainty which, taken together, promote and sustain unsustainability. Education based on this paradigm will close down future possibilities because learners will not be able to conceive and develop real alternatives. Instead education needs to leave its safe haven (embedded in the present ontological framework) and be reconceived as an experimental space for developing radical possibilities based on the assumption of a radical and open understanding of future.

The members of "Konzeptwerk Neue Ökonomie" ("Laboratory for New Economic Ideas") Nadine Kaufmann, Christoph Sanders and Julian Wortmann share the view that educational approaches which fail to address the causes of unsustainability will invariably support the unsustainable status quo (Kaufmann et al. 2019). The authors argue from a degrowth perspective and consider today's popular mentality oriented towards competition and individualism (to the exclusion of collective action and social solidarity) as being at the root of the crisis. They present their own educational work in which they address problematic non-sustainable infrastructures.

Anne-Katrin Holfelder observes the gap between the high-expectation society places on its educational institutions to educate people for creating a sustainable future and the empirical studies that show that people today feel generally incapable of shaping society or their own long-term future (Holfelder 2019). Holfelder criticizes the notion of education understood solely as training (measured on concrete outcomes) and argues for a notion of education as "subjectification" (Biesta 2016) which holds important possibilities for opening futures.

Two contributions in the area of science policy conceptualize future-making practices in terms of their underlying epistemologies. Sean Low and Stefan Schäfer describe different kinds of "future making" in climate engineering approaches (Low and Schäfer 2019). The authors present an analysis of different approaches in climate engineering, based on methodological objectives, epistemologies and user communities. Some of these methods are characterized as deductive, whereby the future is derived from (present) probabilities; others are described as deliberative, whereby a future is conceived, which includes space for projection.

Alejandro Esguerra argues that objects matter in the construction of futures (Esguerra 2019). Instruments, databases and power point presentations perform a political task, whenever they provide consensual knowledge about the future that enables policymakers to design rules in the present. Future objects are also involved in creating futures. For example, Foresight Conferences deal with strategic planning for the future with the aim to pursue novel visions of sustainable futures in the Anthropocene (Hajer and Pelzer 2018). In considering differences between various objects, Alejandro Esguerra elaborates on the sociomaterial politics of anticipation, especially with regard to science policy interaction.

Two contributions engage with questions of how futures for the present and presents for the future are inevitably interconnected in the area of energy policy using the concrete example of energy transition practices. Noel Longhurst and Jason Chilvers map different energy transition visions and show how these visions emerge from multiple contexts beyond mere technical ideas and top-down dictates (Longhurst and Chilvers 2019). The authors argue that such transition visions, even if they appear purely technical, are always normative in promoting specific political and social orders.

Martin David and Matthias Groß investigate processes of abandoning technologies (David and Gross 2019). They call these "exnovations" - the "flipside" or reverse of innovations and real-world experiments. Analysing different cases from the energy sector, David and Groß develop hypotheses of what might be a favourable circumstance for exnovation, for example, an event which is publicly perceived as catastrophic, like the Fukushima nuclear disaster. The authors point to a blind spot in the sustainability literature, which results from the overemphasis placed on innovation.

In the final section of our special feature, two contributions suggest categorizations of how future making is done in sustainability politics. 
Basil Bornemann and Holger Strassheim distinguish different modes of governing time in sustainability politics and propose an analytical scheme of time governance (Bornemann and Strassheim 2019). They reconstruct how time becomes an important factor in sustainability practices: here the role of time can be distinguished, for example, with regard to planning instruments and transition implementation instruments; or time sequences can be looked at as determining factors for governance. These different temporal practices create diverse timescapes of sustainability.

Frank Adloff and Sighard Neckel analyse the sustainability discourse by looking at three possible trajectories of social change: ecological modernization, socio-ecological transformation, and control (Adloff and Neckel 2019). They relate these to imaginaries, practices, and structures, thereby creating a conceptual framework in which one can study new conflicts, inequalities and hierarchies in the sustainable development context.

Open Access This article is distributed under the terms of the Creative Commons Attribution 4.0 International License (http://creativeco mmons.org/licenses/by/4.0/), which permits unrestricted use, distribution, and reproduction in any medium, provided you give appropriate credit to the original author(s) and the source, provide a link to the Creative Commons license, and indicate if changes were made.

\section{References}

Adam B (1998) Timescapes of modernity: the environment and invisible hazards. Routledge, London

Adam B (2010) Future Matters: challenge for social theory and social inquiry. Cultura e comunicazione 1:47-55

Adam B, Groves C (2007) Future matters. Action, knowledge, ethics (Supplements to The study of time). Brill, Leiden

Adloff F, Neckel S (2019) Futures of sustainability as modernization, transformation and control. A conceptual framework. Sustain Sci

Amsler S (2019) Gesturing towards radical futurity in education for alternative futures. Sustain Sci

Appadurai A (2013) The future as cultural fact. Essays on the global condition. Verso, London

Arendt H (1958) The human condition. University Presse, Chicago

Augé M (2014) The future. Verso, London

Beck S, Mahony S (2017) The IPCC and the politics of anticipation. Nat Clim Change 7:311-313

Biesta G (2016) Good education in an age of measurement. Routledge, London

Bornemann B, Strassheim H (2019) Governing time for sustainability-analyzing the temporal implications of sustainability governance. Sustain Sci

Butler J (2004) Undoing gender. Routledge, New York

Butler J (2015) Notes toward a performative theory of assembly. University Press, Cambridge

Caney S (2009) Climate change and the future: discounting for time, wealth, and risk. J Soc Philos 40:16-186

David M, Gross M (2019) Futurizing politics and the sustainability of real-world experiments: What role of innovation and exnovation in the German energy transition? Sustain Sci
Esguerra A (2019) Future Objects: Tracing the Socio-Material Politics of Anticipation. Sustain Sci

Faets S, Tamoudi N (2017) Neue Perspektiven auf die normativen Grundlagen der Debatte um intergenerationelle Gerechtigkeit. www.hfph.de/forschung/drittmittelprojekte/zukuenftige-gener ationen/publikationen/neue-perspektiven-auf-die-normativen -grundlagen-der-debatte-um-intergenerationelle-gerechtigkeit. pdf/view. Accessed 28 June 2018

Fritsch M (2018) Taking turns with the Earth: phenomenology, deconstruction, and intergenerational justice. Stanford University Press, Stanford

Granjou C, Walker, Salazar J (2017) Guest Editorial to the special issue 'Politics of Anticipation: on knowing and governing environmental futures'. Futures 92:1-4

Groves C (2014) Care, uncertainty and intergenerational ethics. Palgrave Macmillan, Basingstoke

Groves C (2019) Sustainability and the future: reflections on the ethical and political significance of sustainability. Sustain Sci

Hajer M, Pelzer P (2018) 2050 - an energetic odyssey. Understanding 'Techniques of Futuring' in the transition towards renewable energy. Energy Res Soc Sci 44:222-231

Hicks JR (1976) Some questions of time in economics. In: Georgesçu-Roegen N, Tang AM, Westfield FM, Worley JS (eds) Evolution, welfare and time in economics: essays in honor of Nicholas Georgescu-Roegen. Lexington Books, Lanham, pp $135-151$

Holfelder A-K (2019) Towards a sustainable future with education? Sustain Sci

Hölscher L (2019) Future pasts. About a form of thought in modern society. Sustain Sci

Kaufmann N, Sanders C, Wortmann J (2019) building new foundations. the future of education from a degrowth perspective. Sustain Sci

Kelz RJ (2019) Thinking about future/democracy—-towards a political theory of futurity. Sustain Sci

King V (2013) Die Entstehung des Neuen in der Adoleszenz. Springer VS, Wiesbaden

King V (2015) Die Zukunft der Nachkommen. Gegenwärtige Krisen der Generativität. Zeitschrift für Psychologie und Gesellschaftskritik, Schwerpunktheft sozialer Wandel und Subjektivität 39:27-53

Koselleck R (2004) Futures past. On the semantics of historical time. Columbia University Press, New York

Leccardi C (2012) Young People's Representations of the Future and the Acceleration of Time. A Generational Approach. Diskurs Kindheits- und Jugendforschung 7:59-73

Longhurst N, Chilvers J (2019) Mapping diverse visions of energy transitions: co-producing socio-technical imaginaries. Sustain Sci

Lövbrand E, Beck S, Chilvers J, Forsyth T, Hedrén J et al (2015) Who speaks for the future of Earth? How critical social science can extend the conversation on the Anthropocene. Glob Environ Change 32:211-218

Low S, Schäfer S (2019) Tools of the trade: practices and politics of researching the future in climate engineering. Sustain Sci

Luhmann N (1990) Die Zukunft kann nicht beginnen: Temporalstrukturen der modernen Gesellschaft. In: Sloterdijk P (ed) Vor der Jahrtausendwende: Berichte zur Lage der Zukunft. Suhrkamp, Frankfurt a. M., pp 119-150

Milkoreit M (2016) The promise of climate fiction-imagination, storytelling and the politics of the future. In: Wapner P, Elver H (eds) Reimagining climate change. Routledge, New York, pp 171-191

Nowotny H (1994) Time: the modern and postmodern experience. Polity Press, Cambridge

Ramsey FP (1928) A mathematical theory of saving. Econ J $38 \cdot 543-559$ 
Rosa H (2016) Resonanz: Eine Soziologie der Weltbeziehung. Surhkamp, Berlin

Sardar Z (1999) Orientalism. Open University Press, Buckingham

Thompson DF (2010) Representing future generations. Political presentism and democratic trusteeship. Crit Rev Int Soc Polit Philos 13:17-37

Van Vuuren D, Stehfest E, Den Elzen M, Deetman S, Beltran A, Oostenrijk R (2011) Exploring the possibility to keep global mean temperature change below 2c. Clim Change 109:95-116

Vervoort J, Gupta A (2018) Anticipating climate futures in a $1.5^{\circ} \mathrm{C}$ era: the link between foresight and governance. Curr Opin Environ Sustain 31:104-111
WCED (1987) Report of the World Commission on Environment and Development: our common future (Brundtland Report). Oxford University Press, Oxford

Wright EO (2010) Envisioning real utopias. Verso, London

Zürn M, Binder M, Ecker-Ehrhardt M (2012) International authority and its politicization. Int Theory 4:69-106

Publisher's Note Springer Nature remains neutral with regard to jurisdictional claims in published maps and institutional affiliations. 